ppi $201502 Z U 4645$

Esta publicación científica en formato digital es continuidad de la revista impresa ISSN-Versión Impresa 0798-1406 / ISSN-Versión on line 2542-3185Depósito legal pp $197402 Z$ U34

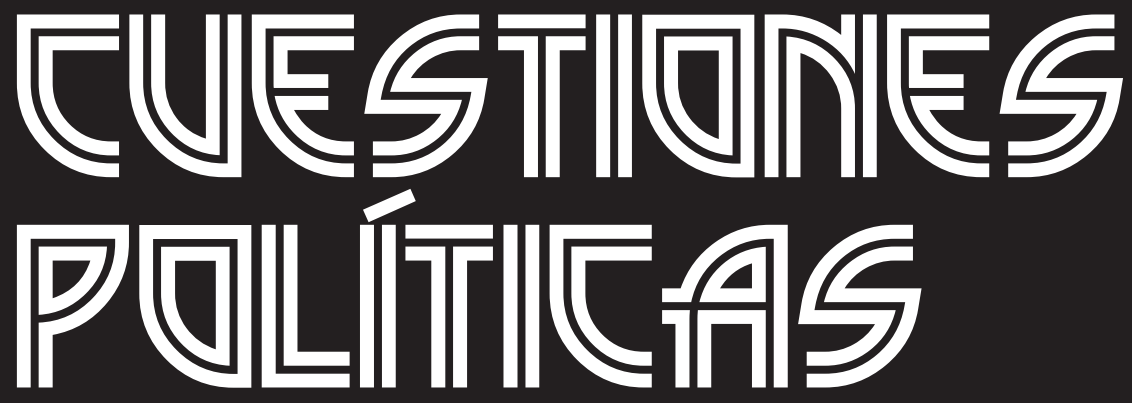

Instituto de Estudios Políticos y Derecho Público "Dr. Humberto J. La Roche" de la Facultad de Ciencias Jurídicas y Políticas de la Universidad del Zulia Maracaibo, Venezuela
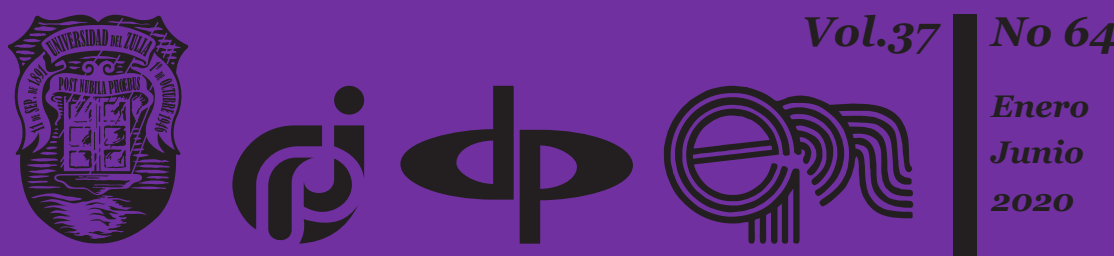


\title{
Bankruptcy Procedure for Individuals in Russia and the USA: Comparative Legal Analysis
}

\author{
Yuliya V. Boltenkova * \\ Vladimir S. Sinenko ** \\ Sergey A. Rubanov *** \\ Oksana S. Lilikova ${ }^{* * * *}$ \\ Aleksey Yu. Gordeev *****
}

\section{Abstract}

Bankruptcy is the legitimate procedure by which monetarily troubled firms, people, and sporadically governments settle their obligations. The insolvency procedure for firms assumes a focal job in financial aspects, since rivalry drives the most wasteful firms bankrupt, subsequently raising the normal proficiency level of those remaining. This study provides a comparative analysis of the most significant aspects of bankruptcy for individuals in Russia and the United States. The objective of the study was to determine the conditions involved in declaring a citizen insolvent in US and Russian law, for which we studied the ways of filing applications in these countries, as well as some methods of abuse by creditors that reduce the effectiveness of the bankruptcy institution, and the ways to minimize them. Based on the results of the analysis, proposals were made to improve the legislation that governs people's bankruptcy. These proposals are based on the positive experience of the United States in the field of legal regulation of insolvency institutions.

Keywords: bankruptcy of individuals; restructuring; settlement; creditor; debtor.

Belgorod State University, 85 Pobedy Street, Belgorod, the Belgorod region, 308015, Russia. Email: boltenkova@bsu.edu.ru.

** Putilin Belgorod Law Institute of Ministry of the Interior of Russia, 71 Gorky Street, Belgorod, the Belgorod region, 308024, Russia. Email: sinenko@bsu.edu.ru.

*** Belgorod State University, 85 Pobedy Street, Belgorod, the Belgorod region, 308015, Russia. Email: rubanov@bsu.edu.ru.

**** Belgorod State University, 85 Pobedy Street, Belgorod, the Belgorod region, 308015, Russia. Email: strebkova@bsu.edu.ru.

***** Putilin Belgorod Law Institute of Ministry of the Interior of Russia, 71 Gorky Street, Belgorod, the Belgorod region, 308024, Russia. alexis8178@mail.ru.

Recibido el: 10/10/2019.

Aceptado: 12/04/2020. 


\section{Procedimiento de quiebra para personas en Rusia y Estados Unidos: análisis legal comparativo}

\section{Resumen}

La bancarrota es el procedimiento legítimo por el cual las empresas, las personas y los gobiernos esporádicamente con problemas monetarios liquidan sus obligaciones. El procedimiento de insolvencia para las empresas asume un trabajo focal en los aspectos financieros, ya que la rivalidad lleva a la quiebra a las empresas más derrochadoras, aumentando posteriormente el nivel de competencia normal de las restantes. Este estudio proporciona un análisis comparativo de los aspectos más significativos de la quiebra bancaria para individuos en Rusia y los Estados Unidos. El objetivo del estudio fue determinar las condiciones involucradas en la declaración de un ciudadano insolvente en las leyes de EE. UU. Y Rusia, para lo cual estudiamos las formas de presentar solicitudes en estos países, así como algunos métodos de abuso por parte de los acreedores que reducen la efectividad de la institución de quiebra, y las formas de minimizarlos. Con base en los resultados del análisis, se hicieron propuestas para mejorar la legislación que rige la quiebra de las personas. Estas propuestas se basan en la experiencia positiva de los Estados Unidos en el campo de la regulación legal de las instituciones de insolvencia.

Palabras clave: quiebra de particulares; reestructuración; liquidación; acreedor; deudor.

\section{Introduction}

The main goal of the state is to protect the rights and freedoms of people, regardless of its financial situation and life situation. Russia is no exception, which is why in Art. 2 of the Constitution of the Russian Federation, the principle of the priority of the rights and freedoms of man and citizen is formulated, as well as the obligation of the state to protect and comply with them (The Constitution of the Russian Federation, 1993).

From the above provision it follows that the state should help citizens maintain a decent standard of living. However, until 2015, the legislative regulation of the mechanism of such support was not complete. There was no effective way to help a citizen, which, due to a combination of circumstances, turned out to be insolvent. In 2015, the legislator bridged this gap by significantly changing the regulatory framework for the bankruptcy of individuals and significantly expanding the capabilities of citizens in this area. 
Yuliya V. Boltenkova, Vladimir S. Sinenko, Sergey A. Rubanov, Oksana S. Lilikova y Aleksey Yu. Gordeev

The Unified Federal Register of Legally Significant Information on the Facts of the Activities of Legal Entities, Individual Entrepreneurs, and Other Economic Entities has been tracking the dynamics of bankruptcy of citizens for four years. According to the mentioned resource, in 2015, 870 court decisions were passed on declaring citizens insolvent, in 2016 this number increased to 19,574, in 2017 amounted to 29,827, and in 2018 reached 43,984 (Statistical Bulletin of the EFRSB, s.f). 2019 was marked by the largest number of court decisions declaring citizens bankrupt. In the first half of 2019 alone, the courts declared 29017 Russian citizens bankrupt, which is 52.3\% more than in the same period in 2018.

The bankruptcy procedure for individuals in Russia in the current form has been introduced relatively recently and is still at the stage of identifying legal gaps and addressing them. The situation is different in the United States, where a similar procedure has been implemented since 1978 and has already managed to pass approbation in full. Research and comparative analysis of the institution of bankruptcy of individuals in Russia and the United States will allow, based on the positive experience of a foreign country, to identify and find possible solutions to the problematic and debatable issues that currently exist in Russian law. Given the growing number of applications for declaring individual's insolvent (bankrupt), this study is as relevant and timely as possible.

\section{Methods}

Various general scientific methods and the methods of logical cognition are used in the work: analysis and synthesis, systemic, functional and formal-logical approaches. The development of conclusions was facilitated by the application of formal-legal and comparative-legal methods.

\section{Discussion and Results}

Bankruptcy of individuals in Russia is regulated by the Federal Law «On Insolvency (Bankruptcy)», namely, Chapter 10 of the aforementioned regulatory legal act (Federal law № 127-FZ of 26.10.2002), as well as other regulatory legal acts, for example, the Civil Code of the Russian Federation.

In the United States, the Bankruptcy Reform Act (The Bankruptcy Reform Act of 1978), as well as The Bankruptcy Abuse Prevention and Consumer Protection Act (The Bankruptcy Abuse Prevention and Consumer Protection Act of 2005), governs the abuse of rights through bankruptcy procedures, govern the insolvency of citizens. 
The fundamental difference between the bankruptcy of individuals in Russia and the United States lies in the purpose of this procedure. The American legal system is aimed at rehabilitating a citizen who finds himself in a difficult situation, which resulted in his insolvency, so after the bankruptcy procedure he is given the so-called «fresh start», that is, the opportunity to start his professional and economic activities from scratch (Boshkoff, 1995).

Until 2005, US law provided for only one type of bankruptcy, after which a citizen completely got rid of outstanding debt and could continue a measured life without restrictions. However, the frequent cases of abuse of citizens' rights in the framework of the bankruptcy procedure forced the legislator to introduce an additional type of bankruptcy procedure into the Bankruptcy Code. Now in the named regulatory legal act two options are established for the bankruptcy of individuals:

- Liquidation. This is the very «liberal» procedure that existed initially and was regulated by Chapter 7 of the US Bankruptcy Code. A citizen who is declared insolvent after the implementation of this procedure receives a full exemption from debts. His property is being sold, due to which part of the debts is repaid, and the rest is considered repaid, although in fact it is not.

- restructuring. This type of bankruptcy of an individual is regulated by Chapter 13 of the Bankruptcy Code introduced in 2005 and implies an assessment not only of the debtor's existing property, but also of its future income. Part of the property is sold to pay off debt, while leaving the most necessary things to maintain the existence of a citizen. Next, there is a restructuring of the debt remaining after the repayment of debts due to the sold property, which the individual declared insolvent is obligated to repay at the expense of his future income (Korshunov, 2016).

Obviously, the first method is more beneficial for the debtor, and the second is focused on protecting the rights of not only an insolvent citizen, but also his creditors.

Having analyzed the Russian legislation governing the bankruptcy of individuals, it can be concluded that the measures taken against insolvent citizens are much more severe than those implemented in the United States. So, Art. 213.30, 216 of the Federal Law «On Insolvency (Bankruptcy)» as one of the consequences of declaring a citizen bankrupt provides for a ban on filling positions in the governing bodies of a legal entity, a ban on doing business, and the reason for bankruptcy does not matter. Under such conditions, the «fresh start» model cannot be implemented in principle.

We believe that this is not a plus for either citizens or the state, since it negatively affects both the recognized insolvent person and economic development as a whole. 
Yuliya V. Boltenkova, Vladimir S. Sinenko, Sergey A. Rubanov, Oksana S. Lilikova y Aleksey Yu. Gordeev

96 Bankruptcy Procedure for Individuals in Russia and the USA: Comparative Legal Analysis

In addition, it is necessary to consider the reason for the bankruptcy of individuals. Today, the most common reason for declaring bankrupt is the inability to fulfill obligations under a loan or mortgage agreement. We believe that the explanation for this is, on the one hand, the lack of proper financial literacy among persons entering into agreements of the above types with credit and other financial organizations, and, on the other hand, the increase in abuse by financial institutions (Sisemova et al, 2018).

Despite the fact that lawmakers are trying to respond in a timely manner and prevent possible abuse by financial institutions, this is not always possible, as a result of which citizens are in a state of vulnerability.

Nevertheless, the judicial authorities, exercising the rights of a citizen to a fair trial, in exceptional cases go to a meeting with citizens in order to protect them from the arbitrariness of creditors. So, for example, the Judicial Collegium for Economic Disputes of the Supreme Court of the Russian Federation indicated that the ban on the release of the debtor from fulfillment of obligations does not apply to situations where a citizen has shown unreasonableness by assuming excessive debt obligations. In addition, the creditor's references to the unreasonableness of the debtor are completely groundless if the creditor himself before the conclusion of the transaction had reliable information about the financial position of the debtor and could objectively evaluate its ability to return funds. Given that banks are professional participants in the credit market and have ample opportunity to assess the creditworthiness of citizens, when making a positive decision to issue a loan based on reliable information provided by the citizen, the bank's arguments about the unreasonability of the debtor are untenable (Determination of the Judicial Board on economic disputes of the Supreme Court of the Russian Federation from 03.06.2019).

Despite the fact that such an explanation, recognizing the possibility of abuse by credit organizations and aimed at protecting the rights of the debtor, is already a big breakthrough for the Russian institution of insolvency of individuals, such decisions still remain rather exceptions to the general rule.

Turning to the experience of the United States, it should be noted that the American lawmaker took the path of protecting debtors from creditors' abuses as far back as the last century, and the result was the introduction of amendments to the regulatory legal acts, combined in Chapter 11 of the United States Bankruptcy Code (The Code of Laws of the United States of America (U.S.C.)).

The essence of these amendments is to tighten control over financial and credit organizations by the judicial system, law enforcement agencies and specialized public organizations over actions against individual borrowers. It is assumed that these organizations are obliged to comprehensively 
investigate the financial situation of a potential borrower, predict their ability to repay borrowed funds, verify the accuracy of the information provided by them, and issue a loan or enter into another agreement implying the provision of funds only if there is no objective reason to doubt returns them. If financial institutions commit violations against their borrowers, firstly, their chances of collecting debt when declaring a citizen bankrupt according to the previously considered «liquidation» model tend to zero, and secondly, they may be fined increase financial literacy of the population.

Moreover, before applying to the court with a request for debt collection, the lender under US law is obliged to take measures to pre-trial settlement of the conflict, conduct a conversation with the borrower and offer options for paying off the debt, convenient for a citizen in a difficult life situation. Otherwise, the court will not accept the application of the creditor for consideration at all.

Russian courts, when considering a creditor's claim to be included in the register of creditors of an individual with respect to whom bankruptcy proceedings have been instituted, establish only the fact of the debtor's debt to the creditor and a three-month delay in its payment.

Another step towards the formation of a system of protecting citizens in bankruptcy is the position of the Judicial Collegium for Economic Disputes, according to which to confirm that a citizen has debt to the creditor and include the latter in the register of creditors' claims, it is necessary not only to recognize the debtor as having debt, but to present court decision confirming the existence of debt (Determination of the Judicial Board on economic disputes of the Supreme Court of the Russian Federation from 15.12.2016).

We believe that this can be considered a tangible breakthrough in the field of protecting the rights of debtors from arbitrariness by creditors, but this is still not enough.

\section{Conclusion}

By comparing the key points of bankruptcy of individuals in Russia and in the USA, the following conclusions can be drawn.

The American legal system is more liberal towards citizens who find themselves in a difficult life situation, in connection with which the procedure for bankruptcy of individuals in the United States aims to restore insolvent individuals in their rights, and to help return to normal. For this, since 1978, through trial and error, legislation has been formed that regulates the bankruptcy procedure for individuals, and today there is a wide regulatory 
Yuliya V. Boltenkova, Vladimir S. Sinenko, Sergey A. Rubanov, Oksana S. Lilikova y Aleksey Yu. Gordeev

98 Bankruptcy Procedure for Individuals in Russia and the USA: Comparative Legal Analysis

framework in this area, which continues to be supplemented and changed in light of the changes taking place in the country.

Bankruptcy legislation of Russia, unlike the United States, is more aimed at protecting the rights of creditors, and only its second task is to help citizens who find themselves in a difficult economic situation. In addition, Russian legislation governing the institution of bankruptcy of individuals is significantly inferior to the US regulatory framework both in terms of volume and completeness of regulated issues. One of the reasons for this is the relatively recent transformation in the field of legal regulation of the bankruptcy of individuals. That is why it would be advisable to use the positive experience of the United States and use it to improve domestic legislation.

We believe that it would be advisable to adopt the system of the possibility of a separate application for a citizen to declare bankruptcy, as a result of which, according to the first bankruptcy system, he is completely exempted from existing debts, and according to the second - he follows a restructuring plan and gradually repays debts.

In addition, the system of control over credit and financial organizations, implemented in the USA, aimed at minimizing violations against citizen borrowers, is also necessary in Russia. Currently, only the first steps are being taken to minimize such violations, and some of them are reflected not in the legislation, but in the decisions of the courts. Given the fact that judicial precedent in the Russian Federation does not equal the sources of law, the positions expressed in them testify to the readiness of the Russian lawmaker to changes in the field of legal regulation of bankruptcy of individuals, but they are not such changes by themselves.

It is necessary to take into account the fact that citizens also abuse the right, and the introduction of a separate application system, contributing to a more complete protection of their rights, at the same time, creates favorable conditions for increasing the excessive use by debtors of their opportunities. However, this does not mean that you should not change the current state of affairs and turn a blind eye to existing problems in the field of bankruptcy of individuals. We believe that a positive effect can be achieved through the phased introduction of such a system, coupled with an increase in the legal and economic literacy of the population, also implemented in the United States at the expense of funds received from fines of financial institutions that were noticed for abuse of their rights.

In order to solve problems with abuse of rights by both creditors and debtors during bankruptcy proceedings, it is also possible to tighten liability for dishonesty of both parties. For example, in relation to creditors represented by banks and other financial organizations, following the example of American colleagues, it is advisable to introduce a system of 
fines for dishonest verification of the financial situation of a debtor when providing him a loan. It would also be logical to direct the funds received as a result of fines to increase the legal economic literacy of citizens, since they are more vulnerable than financial organizations.

Studying the positive experience gained by the United States over several decades, analyzing it and adapting it to the conditions of Russian legal realities will allow us to set the vector for the development of the bankruptcy procedure for individuals in Russia and to improve this institution of law. Having analyzed the changes in Russian legislation regarding the conduct of bankruptcy proceedings for individuals and abuse of creditors' rights during the bankruptcy proceedings for individuals, it should be noted that the legislator is ready for the next stage of the reform of the bankruptcy institution and the introduction of more liberal provisions for insolvent citizens. That is why carrying out comparative studies in this area is of particular interest and relevance both for the theory of law and for the subsequent practical implementation of conclusions. This is especially true for countries with different legal systems (Borisov et al, 2018).

\section{Conflict of Interest}

The authors confirm that the information provided in the article does not contain a conflict of interest.

\section{Bibliographic References}

THE CONSTITUTION OF THE RUSSIAN FEDERATION. 1993. (was adopted at National Voting on December 12, 1993). Available online. In: http:// www.constitution.ru/en/10003000-01.htm. Date of consultation: 08/01/2020.

FEDERAL LAW № 127-FZ of 26.10.2002 (Ed. of 27.12.2019) «On insolvency (bankruptcy)». Rossiyskaya Gazeta. No. 209-210. 02.11.2002.

DETERMINATION OF THE JUDICIAL BOARD ON ECONOMIC DISPUTES OF THE SUPREME COURT OF THE RUSSIAN FEDERATION FROM 03.06.2019 No. 305-ES18-26429 in case no. A41-20557/2016. Available online. In: http://www.consultant.ru/cons/cgi/online.cgi?req= home\& utm_csource=online\&utm_cmedium=button. Date of consultation: 08/01/2020. 
Yuliya V. Boltenkova, Vladimir S. Sinenko, Sergey A. Rubanov, Oksana S. Lilikova y Aleksey Yu. Gordeev

100

Bankruptcy Procedure for Individuals in Russia and the USA: Comparative Legal Analysis

DETERMINATION OF THE JUDICIAL BOARD ON ECONOMIC DISPUTES OF THE SUPREME COURT OF THE RUSSIAN FEDERATION FROM 15.12.2016 no. 305-ES16-12960 in the case no. A40-192008/2015. Available online. In: http://www.consultant.ru/cons/cgi/online. cgi?req= home\& utm_csource=online\&utm_cmedium=button. Date of consultation: 08/01/2020.

KORSHUNOV, Ivanova Sarbinaz. 2016. "Brief justification of the possibility of introducing "notification bankruptcy» of consumers in the Russian Federation, taking into account the experience of the United States" In: Business law. The application of «law and business». No 3, pp. 19 - 21.

SISEMOVA, O.B; PCHELKIN, A.V; MAMAKOV, A.M. 2018. "Comparative analysis of the legislation on bankruptcy of individuals in Russia and the United States" In: Journal of foreign legislation and comparative law. No. 5 , pp. 80-87.

STATISTICAL BULLETIN OF THE EFRSB. s/f. Unified Federal register of legally significant information on the facts of activity of legal entities, individual entrepreneurs and other economic entities. Available online. In: https://www.fedresurs.ru/news. Date of consultation: 08/01/2020.

BOSHKOFF, Demitry Gulnur. 1995. "Fresh Start, False Start, or Heard Start?" In: Indiana Law Journal. No. 70, Vol. 2, pp. 549 - 568.

THE BANKRUPTCY ABUSE PREVENTION AND CONSUMER PROTECTION ACT OF 2005. Pub. L. 109-8. Apr. 20. 2005. 119 Stat. 23.

THE BANKRUPTCY REFORM ACT OF 1978. Pub. L. 95 - 598. Nov. 6. 1978. 92 Stat. 2549.

THE CODE OF LAWS OF THE UNITED STATES OF AMERICA. S/f. (U.S.C.). Available online. In: https://www.law.cornell.edu/uscode/text. Consulted: 08/01/2020.

BORISOV, Gulnur Andrey; TSUKANOVA, E.Y; TONKOV, E.E; SINENKO, V.S; ZINKOVSKIY, M.A. 2018. "The place of the russian legislation in the modern legal systems” In: Revista Publicando. No 5(16 (1), pp. 822-828. 

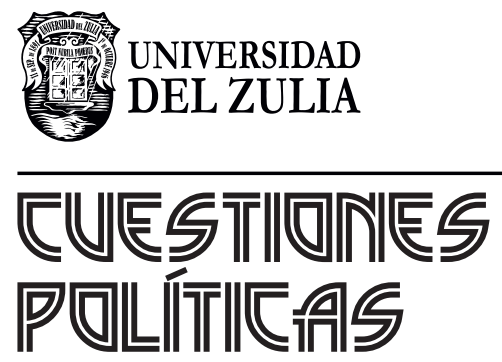

Vol. $37 \mathrm{~N}^{\circ} 64$

Esta revista fue editada en formato digital y publicada en junio de 2020, por el Fondo Editorial Serbiluz, Universidad del Zulia. Maracaibo-Venezuela 